RESEARCH ARTICLE

\title{
Impact of Vasicine on Growth, physiological traits and Yield of Tomato
}

Sivakumar, R1* and P. Jeyakumar2

1Regional Research Station, Tamil Nadu Agricultural University, Paiyur

2Department of Crop Physiology, Tamil Nadu Agricultural University, Coimbatore

\begin{abstract}
Vasicine is a quinazoline alkaloid present in Adulsa. An experiment was conducted to assess the impact of vasicine on growth, photosynthesis and yield of tomato under pot culture. Vasicine was applied as soil application in the form of vigo @ $4 \mathrm{~kg} \mathrm{acre}^{-1}$ (50\% as basal and $50 \%$ at 15 days after transplanting), and as foliar application in the form vigo @ $2 \mathrm{~mL} \mathrm{~L}^{-1}$ at 15 and 30 DAT and both combined soil and foliar application. Combined application of vasicine in the form of vigo through soil and foliar spray increased leaf area by $16.9 \%$ and soluble protein by $24.02 \%$ over control. This is on par with foliar application of vigo @ $2 \mathrm{~mL} \mathrm{~L}^{-1}$ twice at 15 and 30 days after transplanting. Tallest plant $(116.56 \mathrm{~cm})$ and longest root length $(73.25 \mathrm{~cm})$ were observed in combined soil and foliar application of vasicine. Combined application recorded higher total chlorophyll content $\left(1.34 \mathrm{mg} \mathrm{g}^{-1}\right)$ followed by foliar application $\left(1.18 \mathrm{mg} \mathrm{g}^{-1}\right)$ compared to control $\left(1.09 \mathrm{mg} \mathrm{g}^{-1}\right)$. Combined application of vasicine through soil and foliar recorded the highest fruit yield of $26.23 \mathrm{t} \mathrm{ha}^{-1}$ which is on par with foliar spray of vigo @ $2 \mathrm{~mL} \mathrm{~L}^{-1}\left(25.68 \mathrm{t} \mathrm{ha}^{-1}\right)$ and least recorded in control $\left(21.52 \mathrm{t} \mathrm{ha}^{-1}\right)$. Vasicine might compose of growth hormones like auxin, gibberellins and cytokinin, which are playing a major role in plant growth and metabolism. Hence, the new biostimulant vasicine showed its positive impact on growth and yield in tomato.
\end{abstract}

Keywords: Vasicine; Tomato; Leaf area; Chlorophyll; Soluble protein; Yield

\section{INTRODUCTION}

Tomato (Solanum lycopersicum L.) belongs to the family Solanaceae and important vegetable crop with high amounts of vitamins A, B and C. India is the second-largest producer of tomato, accounting for $11.10 \%$ of the world's production. The popularity of tomato is rising among consumers because of its lycopene and $\beta$-carotene, which are good anti-oxidants (Erica et al., 2010). Tomato has recently gained attention concerning the prevention of cancer, cardiovascular risk, and slowing down cellular aging (Abdel, 2012). Magadoff and Tokar (2009) stated that $12 \%$ of the global population suffer from hunger and live without secure access to quality food. To achieve nutritional security, quantity and quality of the produce like tomato may be increased. There is a need of the hour to increase the production and productivity of tomato by using plant growth regulators and any new biostimulants. Biostimulants are biologically derived additive products used in crop production to enhance plant growth, health and productivity. Giannattasio et al. (2013) reported that the biostimulants could enhance the activity of rhizosphere microbes and soil enzymes, hormone/growth regulators in soil and plants, and the photosynthetic process. For instance, several biostimulants contain hormones, such as auxins (Jindo et al., 2012), gibberellins and cytokines (Pizzeghello et al., 2013) and triacontanol (Ertani et al., 2012), which are recognized as the main active components responsible for the beneficial effects on plant growth. Generally, most of the biostimulants come under plant growth regulators.

Natural products remain the most important source for the discovery of new and potential biostimulants. Adhatoda vasica (L.), known commonly as Malabar nut tree, is a shrub growing throughout India. The plant is used in India's indigenous system of medicine and is a well-known medicine in both Ayurvedic and Unani Systems (Kapoor, 2001). Vasicine contains one phenolic hydroxyl, which is responsible for anti-microbial and anti-oxidant effects. Current research demonstrated that vasicine regulates the major metabolic enzymes responsible for the glucuronidation of vitamin metabolism (Dan et al., 2019). 
Quinazoline alkaloids present in the leaves are established as an active principle - vasicine. The plant contains alkaloids such as vasicine, vasicinone, deoxyvasicine, vasicol, adhatodinine, and vasicinol (Claeson et al., 2000). Several studies reported the antioxidant effects of vasicine acetate obtained from Adhatoda vasica leaves (Duraipandiyan et al., 2015). Hence, the present study is undertaken to investigate the impact of vasicine on growth, photosynthesis and yield of tomato. The study of the impact of vasicine on the plant is meager, since it is the first study undertaken.

\section{MATERIAL AND METHODS}

A pot culture experiment was conducted during 2017 - 2019. Soil mixture was prepared by using red soil, vermicompost and sand in the ratio of 3:2:1. Pots were filled with $15 \mathrm{~kg}$ of soil. Transplanting was carried out with $25^{\text {th }}$ days old seedlings in pots. Basal application of urea, superphosphate and potash was made before transplanting as per the treatment schedule. The experiment was laid out in a completely randomized block design with three replications. Irrigation was given once in five days and plant protection measures were carried out as per the TNAU Crop Production guide recommendations.

The following treatments like recommended fertilizer (RF) (150 nitrogen in the form of urea, 100 phosphorus in the form of superphosphate and 50 potassium in the form of muriate of potash $\mathrm{kg} \mathrm{ha}^{-1}$ ) and foliar spray of triacontanol (1 ppm) at 15 days after transplanting, RF + soil application of vasicine @ $4 \mathrm{~kg} \mathrm{acre}^{-1}$ (50\% as basal \& 50\% at 15 DAT), RF + foliar application of vasicine @ $2 \mathrm{~mL} \mathrm{~L}^{-1}$ at 15 and 30 DAT, RF + soil application of vasicine @ 4 kg acre ${ }^{-1}$ (50\% as basal \& 50\% at 15 DAT) + foliar application of vasicine @ $2 \mathrm{~mL} \mathrm{~L}^{-1}$ at 15 and 30 DAT were used for this experiment. Vasicine was obtained in the name of VIGO from Bio products Division, Research and Development Centre, Coromandel International Limited, Tamil Nadu, India. Foliar application was given by using hand-operated high volume sprayer to wet the plant completely during evening hours.

Plant height was measured from the soil surface to the tip of the growing point and expressed as $\mathrm{cm}$ plant $^{-1}$. The plant was uprooted from the pot and the root was taken with minimum damage, and the length from the cotyledonary node to the root tip was measured and expressed as $\mathrm{cm}_{\text {plant }}{ }^{-1}$. Leaf area per plant was measured using a leaf area meter (LICOR, Model LI 3000) and expressed as cm² plant $^{-1}$. These growth parameters were measured during two growth stages viz. at 60 and 90 days after transplanting.

Chlorophyll $a$, chlorophyll $b$ and total chlorophyll content were estimated following the method suggested by Yoshida et al. (1971) and expressed as $\mathrm{mg} \mathrm{g}^{-1}$ fresh weight. Soluble protein content of leaf was estimated as per the method of Lowry et al. (1951) and expressed as $\mathrm{mg} \mathrm{g}^{-1}$ fresh weight. The total weight of fruits harvested from each plant from all picking was added, and yield per plant was worked out, and estimated fruit yield was obtained and expressed as t ha-1. The data on various parameters were analyzed statistically as per the procedure suggested by Gomez and Gomez (1984). Wherever the treatment differences were found significant, critical differences were worked out at five per cent probability level and the values were furnished.

\section{RESULTS AND DISCUSSION}

Among the treatments, application of a recommended dose of fertilizers (RDF) along with soil application of vasicine @ $4 \mathrm{~kg}$ acre $^{-1}$ and foliar spray of vasicine @ $2 \mathrm{~mL} \mathrm{~L}^{-1}$ recorded highest plant height of $100.07 \mathrm{~cm}$ and $116.56 \mathrm{~cm}$ during 60 and 90 DAT, respectively.

Table 1. Impact of vasicine on growth parameters in tomato

\begin{tabular}{|c|c|c|c|c|c|c|}
\hline \multirow[t]{2}{*}{ Treatments } & \multicolumn{2}{|c|}{ Plant height (cm) } & \multicolumn{2}{|c|}{ Root length (cm) } & \multicolumn{2}{|c|}{ Leaf area $\left(\mathrm{cm}^{2}\right.$ plant $\left.^{-1}\right)$} \\
\hline & 60 DAT & 90 DAT & 60 DAT & 90 DAT & 60 DAT & 90 DAT \\
\hline $\mathrm{T}_{1}:$ Control & 85.84 & 102.00 & 58.20 & 62.50 & 2538.40 & 2409.40 \\
\hline $\mathrm{T}_{2}:$ Vasicine - Soil & 95.66 & 107.54 & 66.70 & 68.75 & 2785.72 & 2419.68 \\
\hline $\mathrm{T}_{3}$ : Vasicine - Foliar & 88.34 & 111.80 & 64.50 & 65.80 & 2776.30 & 2580.17 \\
\hline $\mathrm{T}_{4}: \mathrm{T}_{2}+\mathrm{T}_{3}$ & 100.07 & 116.56 & 71.40 & 73.25 & 3068.53 & 2816.90 \\
\hline SEd & 2.50 & 3.04 & 1.64 & 1.29 & 81.73 & 59.84 \\
\hline$C D(P=0.05)$ & 5.78 & 7.01 & 3.78 & 2.98 & 188.46 & 137.98 \\
\hline
\end{tabular}

This is followed by foliar application of vasicine @ $2 \mathrm{~mL} \mathrm{~L}^{-1}$ with RDF. At the same time, control recorded the lowest plant height at both the growth stages $(85.84$ and $102.00 \mathrm{~cm})$. Soil application of vasicine increased the plant height quickly at an early stage compared to foliar spray at 60 DAT. However, foliar application achieved higher plant height at 90 DAT over soil application, whereas combined application showed its superiority over the other two. The increment of plant height by vasicine might be due

$107 \mid 10-12$ | 2 
to its biostimulant action by enhancing cell division and cell elongation by cytokinin and auxin function.

Combined application of RDF along with vasicine significantly influenced the root length of tomato at both the stages of crop growth (Table 1). Application of vasicine either soil @ 4 kg acre ${ }^{-1}(66.70$ and 68.75 $\mathrm{cm}$ ) or foliar spray @ 2ml/lit (64.50 and $65.80 \mathrm{~cm}$ ) or in combination ( 71.40 and $73.25 \mathrm{~cm}$ ) recorded the longer roots when compared to control (58.20 and $62.50 \mathrm{~cm}$ ) at 60 and 90 DAT respectively. Root length plays a major role in the absorption of water and nutrients necessary for normal plant growth. The increment of root length by applying vasicine might be due to its action on phosphorus mobilization in soil and stimulate the action of cell division. Aremu et al. (2015) registered that biostimulants' mode of action is equally diverse and may include the activation of nitrogen metabolism or phosphorus release from soils, generic stimulation of soil microbial activity, or root stimulation growth and enhanced plant establishment.

Table 2. Impact of vasicine on photosynthetic parameters in tomato

\begin{tabular}{lrrrr}
\hline \multicolumn{1}{c}{ Treatments } & $\begin{array}{c}\text { Chlorophyll a } \\
\left(\mathrm{mg} \mathrm{g}^{-1}\right)\end{array}$ & $\begin{array}{c}\text { Chlorophyll b } \\
\left(\mathrm{mg} \mathrm{g}^{-1}\right)\end{array}$ & $\begin{array}{c}\text { Total chlorophyll } \\
\left(\mathrm{mg} \mathrm{g}^{-1}\right)\end{array}$ & $\begin{array}{c}\text { Soluble protein } \\
\left(\mathrm{mg} \mathrm{g}^{-1}\right)\end{array}$ \\
\hline $\mathrm{T}_{1}:$ Control & 0.74 & 0.39 & 1.16 & 11.24 \\
$\mathrm{~T}_{2}:$ Vasicine - Soil & 0.87 & 0.41 & 1.29 & 12.59 \\
$\mathrm{~T}_{3}:$ Vasicine - Foliar & 1.07 & 0.48 & 1.58 & 13.76 \\
$\mathrm{~T}_{4}: \mathrm{T}_{2}+\mathrm{T}_{3}$ & 1.11 & 0.48 & 1.61 & 13.94 \\
\hline $\mathrm{SEd}$ & 0.02 & 0.01 & 0.03 & 0.62 \\
\hline $\mathrm{CD}(\mathrm{P}=0.05)$ & 0.05 & 0.03 & 0.07 & 1.44 \\
\hline
\end{tabular}

Leaf area is a fundamental determinant of the total photosynthesis of a plant. Leaf area always shows a positive relationship with net photosynthetic activity because leaf enlargement is attributed to increased number and width of grana and a high degree of stacking of grana (Fortun et al., 1985). The study revealed that RDF, along with vasicine, significantly increased the leaf area compared to control at both the growth stages of crop viz. 60 and 90 days after transplanting.

Among the treatments, combined application (Soil + foliar) recorded the maximum leaf area of 3068.53 and $2816.90 \mathrm{~cm}^{2}$ plant $^{-1}$ at 60 and 90 DAT respectively, followed by foliar application. The lowest leaf area of 2409.40 was recorded by control, which is on par with soil application of vasicine (2419.68). This result indicated that the soil application of vasicine is not enough to maintain the leaf area during the fruiting stage (Table 1). The declined leaf area from 60 DAT to 90 DAT is might be due to senescence. The increment of leaf area by vasicine over control might be due to its plant growth promotion activity through plant growth regulators like auxin and gibberellins.

Biostimulant is composed of cytokinin, indole butyric acid, and gibberellic acid, which increased the seedling emergence percentage of cotton as well as plant height and leaf area (Santos and Vieira, 2005). Hence, the present study corroborated with earlier finding.

Chlorophyll content was measured during fruit formation stage and had significant difference due to an application of vasicine either through soil or foliar or in combination (Table 2). Among the treatments, total chlorophyll content was higher in combined application (1.61 $\mathrm{mg} \mathrm{g}^{-1}$ ) which is on par with foliar application of vasicine @ $2 \mathrm{~mL} \mathrm{~L}^{-1}$ (1.58 $\left.\mathrm{mg} \mathrm{g}^{-1}\right)$. In contrast, control plants registered lowest total chlorophyll content of $1.16 \mathrm{mg} \mathrm{g}^{-1}$ followed by soil application of vasicine $\left(1.29 \mathrm{mg} \mathrm{g}^{-1}\right)$. Foliar application of vasicine had a significant impact on total chlorophyll content compared to soil application might be due to direct contact of biostimulant to the source of chlorophyll synthesis. However, the impact of vasicine on chlorophyll a was higher than chlorophyll $b$. Many authors have observed that plant-based biostimulants often increase the color of leaves by stimulating chlorophyll biosynthesis or reducing its degradation (Abbas and Akladious, 2013). Higher chlorophyll content allows for the greater photosynthetic activity of leaves. Bulgari et al. (2014) found that the high concentration of leaf pigments viz. chlorophyll and carotenoids after biostimulant treatments in lettuce. Various biostimulants have been reported to stimulate photosynthesis and plant productivity (Santos et al., 2014) through chlorophyll synthesis. Hence, the present result agreed with these earlier findings.

Diethelm and Shibles (1989) opined that the rubisco content per unit leaf area was positively correlated with that of the leaf's soluble protein content, which is considered an index for assessing the photosynthetic efficiency of crops. The data on soluble protein content had shown significant differences among the treatments (Table 2). Among the treatments, higher soluble protein content was registered in combined application (13.94 $\mathrm{mg} \mathrm{g}^{-1}$ ) 
followed by foliar application (13.76 $\mathrm{mg} \mathrm{g}^{-1}$ ). The lowest soluble protein content of $11.24 \mathrm{mg} \mathrm{g}^{-1}$ was observed in control. Combined application of vasicine with soil and foliar increased soluble protein content up to $22.42 \%$ over control might be due to its positive action on denovo synthesis of amino acids and proteins. Tejada et al. (2016) registered that the foliar spray of bio-stimulator containing sewage sludge caused an increase in maize protein content. The mode of action of biostimulants is often

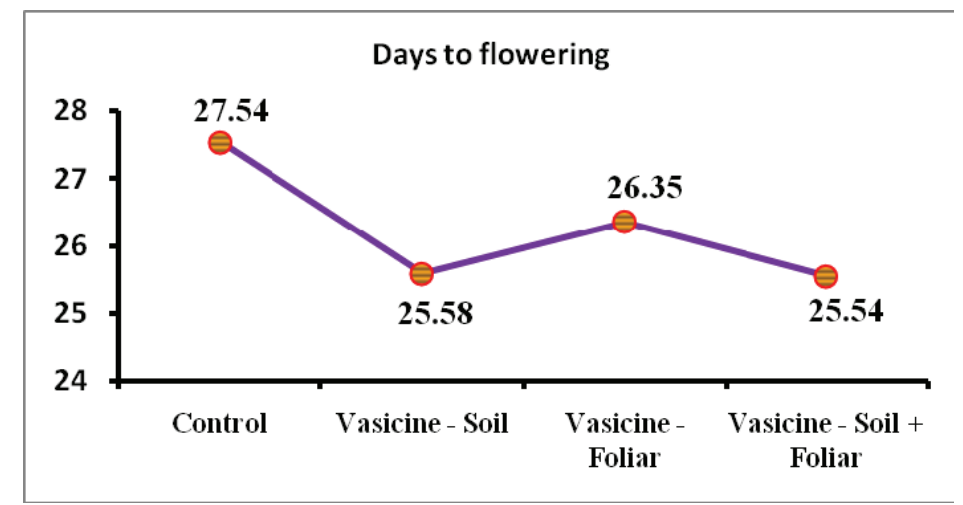

Figure 1. Impact of vasicine on days to flowering in tomato

unknown and hard to identify, because they derive mainly from complex sources containing multiple bioactive components that, together, may contribute to specific effects in plants (Ertani et al., 2013).

The influence of vasicine on days to flowering is very meagre, which is presented in Figure 1 . The maximum days taken for flowering was observed in control (27.54 days), whereas minimum days was observed in $T_{4}$ (25.54) followed $T_{2}$ (25.58) and $T_{3}$ (26.35). Exactly two days early flowering was observed by the application of vasicine compared to control. Interestingly soil application registered earlier flowering compared to foliar application. It might be due to flowering is a long-term process that mainly depends on vegetative growth. Soil application can enhance vegetative growth from germination onwards and complete vegetative growth quickly than foliar spray. Colla and Rouphael (2015) found that a promising and environmental-friendly innovation would be the use of plant biostimulants that enhance flowering, plant growth and crop productivity.

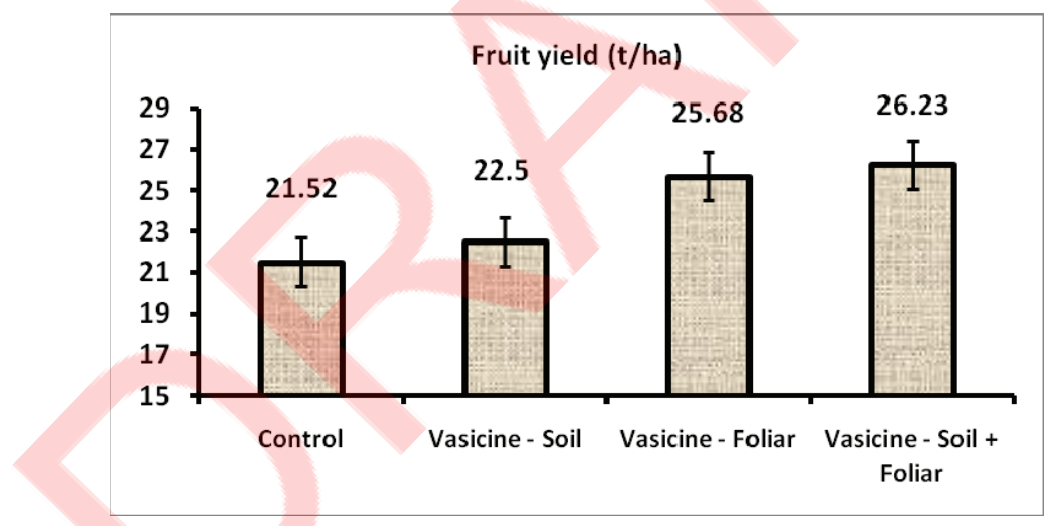

Figure 2. Impact of vasicine on fruit yield in tomato

Combined application of vasicine through soil and foliar recorded $\left(T_{4}\right)$ the highest fruit yield of $26.23 \mathrm{t} \mathrm{ha}^{-1}$ and which is on par with foliar spray @ $2 \mathrm{ml} \mathrm{lit}^{-1}\left(\mathrm{~T}_{3}\right)$ which recorded $25.68 \mathrm{t} \mathrm{ha}^{-1}$. Whereas soil application recorded $22.50 \mathrm{t} \mathrm{ha}^{-1}$ and the control registered the lowest (21.52 t ha-1). Based on yield, combined application and foliar spray showed on par values (Figure 2) compared to soil application might be due to foliar spray during flowering directly contributed to the yield rather than soil application contributed mainly to vegetative growth. The yield increment by the application of vasicine might be due to the increment of root growth, chlorophyll fractions and soluble protein content, which are direct contributors to the photosynthesis and yield.
The popularity of biostimulants in agriculture is associated with the possibility of obtaining higher yields. Biostimulants have a positive effect on yielding plants (Garcia-Martinez, 2010). Paradikovic et al. (2011) reported that the application of biostimulants could be considered as a good production strategy for obtaining high yields of nutritionally valuable vegetables with lower impact on the environment.

\section{CONCLUSION}

The present study concluded that the combined application of vasicine in the form of vigo through soil $\left(4 \mathrm{~kg} \mathrm{acre}^{-1}\right)$ and foliar spray $\left(2 \mathrm{~mL} \mathrm{~L}^{-1}\right)$ along with a recommended dose of fertilizers recorded increased 
leaf area, root length, chlorophyll fractions, soluble protein and fruit yield compared to control in tomato. Compared to a different mode of application, foliar application of vasicine @ $2 \mathrm{~mL} \mathrm{~L}^{-1}$ twice at 15 and 30 days after transplanting is on par vales with the combined application.

\section{FUNDING AND ACKNOWLEDGMENT}

The authors acknowledge the financial support provided to Department of Crop Physiology, Tamil Nadu Agricultural University, Coimbatore by the Bio-products Division, Research and Development Centre, Coromandel International Limited, India (EID / DCM / CBE / CRP / 2017 / R009).

\section{REFERENCES}

Abbas, S.M. and S.A. Akladious. 2013. Application of carrot root extract induced salinity tolerance in cowpea (Vigna sinensis L.) seedlings. Pak. J. Bot., 45: 795-806.

Abdel, M.M.F. 2012. Induced systemic resistance in tomato plants against fusarium wilt diseases. Inter. Res. J. Microbiol., 3: 14-23.

Aremu, A. O., Stirk, W. A., Kulkarni, M. G., Tarkowska, D., Tureckova, V. and J. Gruz. 2015. Evidence of phytohormones and phenolic acids variability in garden-waste-derived vermicompost leachate, a well-known plant growth stimulant. Plant Growth Regul., 75: 483-492.

Bulgari, R., Podetta, N., Cocetta, G., Piaggesi, A. and A. Ferrante. 2014. The effect of a complete fertilizer for leafy vegetables production in family and urban gardens. Bulg. J. Agric. Sci., 20: 1361-1367.

Claeson, U.P., Malmfors, T., Wikman, G. and J. G. Bruhn. 2000. Adhatoda vasica: a critical review of ethnopharmacological and toxicological data. J. Ethnopharm., 72(1-2): 1-20.

Colla, G. and Y. Rouphael. 2015. Biostimulants in horticulture. Sci. Hortic. 196: 1-2.

Dan, L., Lin, Z., Lixin, D., Jinjun, W., Ming, Hu, Zhong, L. and W. Caiyan. 2019. Potential of herb-drug / herb interactions between substrates and inhibitors of UGTs derived from herbal medicines. Pharmacol. Res. https://doi.org/10.1016/j. phrs.2019.104510

Diethelm, R. and R. Shibles. 1989. Relationship of enhanced sink demand with photosynthesis and activity of ribulose 1,5-bisphosphate carboxylase in soybean leaves. J. Plant Physiol., 134: 70-74.

Duraipandiyan, V., Al-Dhabi, N.A., Balachandran, C., Ignacimuthu, S.,C. and K. Balakrishna. 2015. Antimicrobial, antioxidant, and cytotoxic properties of vasicine acetate synthesized from vasicine isolated from Adhatoda vasica L. Biomed. Res. Intl., doi.org/10.1155/2015/727304.

Erica, N.S., Rachel, E.K., Steven, J.S. and G.K. Harris. 2010. An Update on the Health Effects of Tomato Lycopene. Ann. Rev. Food Sci. Tech., 1: 189-210

Ertani, A., Nardi, S. and A. Altissimo. 2013. Long-term research activity on the biostimulant properties of natural origin compounds. Acta Hort., 1009: 181-188.
Ertani, A., Pizzeghello, D., Baglieri, A., Cadili, V., Tambone, F., Gennari, M. and S. Nardi. 2012. Agro-industrial residues and their biological activity on maize (Zea mays L.) metabolism. J. Geochem. Explor., 129: 103-111

Fortun, C., Rapsch, S. and C. Ascaso. 1985. Action of humic acid preparations on leaf development, mineral elements contents and chloroplast ultra structure of ryegrass plants. Photosynthetica, 19: 294-299

Garcia-Martinez, A.M., Diaz, A., Tejada, M., Bautista, J., Rodriguez, B., Santa Maria, C., Revilla, E. and J. Parrado. 2010. Enzymatic production of an organic soil biostimulant from wheat-condensed distiller solubles: Effects on soil biochemistry and biodiversity. Proc. Biochem., 45: 1127-1133.

Giannattasio, M., Vendramin, E., Fornasier, F., Alberghini, S. and A. Squartini. 2013. Microbiological features and bioactivity of a fermented manure product (Preparation 500) used in biodynamic agriculture. J. Microbiol. Biotech., 23: 644-651.

Gomez, K. A. and Gomez, A. A. 1984. Statistical procedures for agricultural research. (2nd Ed.) John Wiley and sons, NewYork, USA.

Jindo, K., Martim, S.A., Navarro, E.C., Perez-Alfocea, F., Hernandez, T., Garcia, C., Aguiar, N.O. and L.P. Canellas. 2012. Root growth promoting by humic acids from composted and non-composted urban organic wastes. Plant and Soil, 353: 209-220.

Kapoor, L.D. 2001. Handbook of Ayurvedic Medicinal Plants. pp. 416-417, CRC Press, Boca Raton, Fla, USA, 2001.

Lowry, O.H., Brought, N.T.R., Farr, L.A. and R. J. Randall. 1951. Protein measurement with folin phenol reagent. J. Biol. Chem., 193: 265-275.

Magdoff, F. and B. Tokar. 2009. Agriculture and food in crisis: An overview. Mon. Rev., 61(3), 1-16.

Paradikovic, N., Vinkovic, T., Vrcek, I.V. and I. Zuntar. 2011. Effect of natural biostimulants on yield and nutritional quality: An example of sweet yellow pepper (Capsicum annuum L.) plants. J. Sci. Food. Agri., 91(12): 2146-52.

Pizzeghello, D., Francioso, O., Ertani, A., Muscolo, A. and S. Nardi. 2013. Isopentenyladenosine and cytokinin-like activity of four humic substances. J. Geochem. Explor., 129: 70-75.

Santos, C.M.G. and E.L. Vieira. 2005. It is made of biostimulant in the germination of grains, seedling vigour and growth of cotton. Magistra, 17:124-130

Santos, V.M., Melo, A.V., Cardoso, D.P., Silva, A.R., Benicio, L.P.F. and E.A. Ferreira. 2014. Development of soybean plants as a function of biostimulants under phosphate fertilization conditions. Biosci. J., 30(4): 1077-1086.

Tejada, M., Rodriguez-Morgado, B., Gomez, I., FrancoAndreu, L., Benitez, C. and J. Parrado. 2016. Use of bio-fertilizers obtained from sewage sludges on maize yield. Eur. J. Agron., 78: 13-19.

Yoshida, S., Forno, D.A. and J. H. Cock. 1971. Laboratory Manual for physiological studies of rice. IRRI Publication, Philippines, pp. 36-37. 